\title{
Deposit Insurance, the Implicit Regulatory Contract, and the Mismatch in the Term Structure of Banks' Assets and Liabilities
}

Jonathan R. Macey $\dagger$

Geoffrey P. Miller $\dagger \dagger$

Professors Macey and Miller explore the relationship between deposit insurance and the mismatch in the term structure of commercial banks' assets and liabilities. After critiquing the traditional regulatory hypothesis, which posits that banks have incentives to fund long-term assets with short-term liabilities because government-sponsored deposit insurance enhances bank credit and subsidizes short-term liabilities, they use public choice theory to argue that a modified version of the regulatory hypothesis is the best explanation for the mismatch in the term structure of banks' assets and liabilities. Finally, they argue that embracing the regulatory hypothesis does not imply acceptance of the government-sponsored deposit insurance scheme as it exists in the U.S. today.

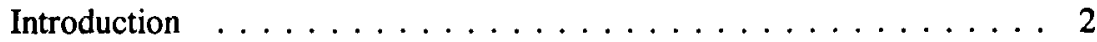

I. The Term Structure Mismatch $\ldots \ldots \ldots \ldots \ldots \ldots$

II. Three Traditional Hypotheses That Do Not Fully Explain the Term Structure Mismatch . . . . . . . . . . . . . . 5

A. The Checking Account Hypothesis ............ 5

B. The Transformation Hypothesis . . . . . . . . . . 7

C. The Demandable Debt and Incentive-Compatible Intermediation Hypothesis . . . . . . . . . . . . . . . . . 10

III. The Regulatory Hypothesis as an Explanation for the Term Structure Mismatch ......................12

†Comell University.

††University of Chicago.

Copyright $* 1995$ by the Yabo Jousnal on Regulation 
IV. The Inadequacy of the Regulatory Hypothesis as an Economic Justification for Federal Deposit Insurance . . . . . . . . . . . . . 14

A. The Unique Role of Banks in the Payments System . . . . . 15

B. The Informational Problems Among Depositors . . . . . . . 15

V. A Public Choice Explanation for Deposit Insurance . . . . . . . . 17

A. Self-Interested Behavior of Affected Groups . . . . . . . . . 18

B. Banks as Economic Beneficiaries of Deposit Insurance . . . . 19

C. The Continuing Existence of Deposit Insurance . . . . . . . 20

D. Alternative Justifications for Deposit Insurance . . . . . . 22

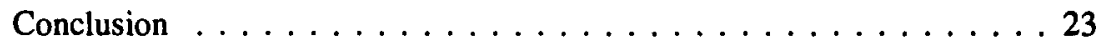

Introduction

This Article explores the relationship between deposit insurance and the mismatch in the term structure of commercial banks' assets and liabilities. Part I recounts how the mismatch between long-term assets and short-term liabilities causes much of the instability in the banking system. Part II criticizes the three principal alternative hypotheses that have been offered to explain this mismatch: (1) the checking account hypothesis, which posits that access to information about depositors' checking accounts helps banks assess their depositors' creditworthiness thereby making it efficient to combine transaction account services (checking accounts) with long-term lending; (2) the transformation hypothesis, which posits that banks serve a societal function by transforming illiquid assets into liquid form; and (3) the incentivecompatible intermediation hypothesis, which posits that demand debt stimulates depositor monitoring and imposes fiscal discipline on bank management by presenting management with the specter of bank runs. Parts III and IV examine and critique the traditional regulatory hypothesis, which asserts that banks have incentives to fund long-term assets with short-term liabilities because government-sponsored deposit insurance enhances bank credit and subsidizes short-term liabilities. Part V uses public choice theory to argue that a modified version of the regulatory hypothesis is the best explanation for the mismatch in the term structure of banks' assets and liabilities and to argue further that embracing the regulatory hypothesis does not imply acceptance of the government-sponsored deposit insurance scheme as it exists in the U.S. today. 


\section{The Term Structure Mismatch}

Many different types of firms extend credit. Similarly, a variety of nonbank firms, most notably money market mutual funds and credit card companies, offer the equivalent of checkable transaction accounts. ${ }^{1}$ What distinguishes banks from other firms is their capital structure, which is unique in two ways. First, banks tend to have very little equity relative to other firms. ${ }^{2}$ While it is not uncommon for manufacturing firms to finance themselves with more debt than equity, banks typically receive ninety percent or more of their funding from debt. ${ }^{3}$ Second, banks' liabilities are largely in the form of deposits that are available to their creditors/depositors on demand, while their assets are primarily in the form of loans that have longer maturities. ${ }^{4}$ The deposit-taking function and the lending function that currently are combined within banks could easily be unbundled and carried out by different firms. For example, it has been proposed that a "narrow bank" could offset demand deposit accounts against short-term, highly liquid money market instruments, instead of against longer-term, illiquid loans. ${ }^{5}$ Indeed, narrow banks already exist in the form of money market mutual funds. Similarly, it would be possible to fund banks' commercial loan portfolios with a larger amount of equity or term debt securities, rather than with demand deposit accounts.

Combining the transactional function with the financial intermediation function can lead to instability due to the interest rate risk brought about by this mismatch. Banks become unprofitable whenever short-term interest rates rise above the rates they receive on the long-term loans they hold in inventory. There are a variety of strategies available to banks for avoiding interest rate risk, including decreasing the maturity of assets, increasing the duration of liabilities, and hedging in the financial futures markets. Nevertheless, interest rate risk remains a considerable source of potential instability for the banking system. $^{6}$

Combining the transactional and commercial lending functions may also cause a collective action problem among depositors, because banks keep only

1. See Jonathan R. Macey \& Geoffrey P. Miller, Nondeposit Accounts and the Future of Bank Regulation, 91 MiCH. L. REV. 237 (1992).

2. See generally Mark J. Roe, Some Differences in Corporate Structure in Germany, Japan, and the United States, 102 YALE L.J. 1927, 1984 (1993).

3. Book value leverage (the ratio of debt to total liabilities and capital) for industrial firms has traditionally run at thirty-three percent, but has increased in recent years to over forty percent. In contrast, book value leverage at commercial banks is over ninety percent. JONATHAN R. MACEY \& GeofFrey P. MiLleR, BANKING LAW AND REgULATION 57 (1992).

4. Id. at 58-59.

5. Leonard I. Nakamura, Commercial Bank Information: Implications for the Structure of Banking, in Structural Change in Banking 131, 134-36 (Michael Klausner \& Lawrence J. White eds., 1993).

6. Id. at 58. 
a fraction of deposits on reserve at any one time. ${ }^{7}$ As a result, banks do not have sufficient funds on hand to satisfy all depositors at once. If a substantial portion of a bank's depositors wanted to withdraw their funds at one time, the bank would be forced to liquidate assets at distress prices. Such a liquidation would render the bank insolvent and jeopardize the interests of those depositors who were not attempting to obtain immediate repayment.

Thus, the argument goes, if bad news circulates about a bank and some depositor decides to withdraw his funds from the bank, other depositors may rationally conclude that they must do the same to avoid being left with nothing. In other words, because the first depositors to attempt to reclaim their funds will be repaid in full, while, in the absence of government guarantees, the last depositors will not receive anything, a me-first mentality is likely to sweep depositors into a mad frenzy to reclaim their funds.

According to this analysis, bank failures can occur even in solvent banks. Such failures occur because "the existence of bank runs does not require any loss in the value of the underlying assets [of the bank]. Even without exogenous fluctuations in the real or nominal value of bank assets, runs can occur since the cost of liquidating assets can make a run self-fulfilling. ${ }^{8}$ The idea that the collective action problem among bank depositors can cause the failure of a solvent bank is often used to justify special regulatory treatment for banks. Deposit insurance aims to solve this collective action problem by eliminating the incentive for any single depositor to rush to demand repayment of his deposits.

This analysis is flawed because it does not take into account the ability of markets to solve the collective action problem among depositors at low cost through private contracts between banks and their depositors. The reason the collective action problem exists is the asymmetry between the maturity structure of banks' assets and their liabilities. But there is nothing to prevent banks from tailoring their asset portfolios to match their liabilities by purchasing highly liquid, short-term assets. Such tailoring would greatly mitigate the collective action problem facing depositors. Thus, to understand the persistence of the mismatch in the term structure of banks' assets and liabilities, one should consider whether there are independent economic explanations of the phenomenon.

7. Under current law, depository institutions generally must hold ten percent of the amount of their transaction deposits in reserve. MACEY \& MILLER, supra note 1, at 238-39.

8. Douglas W. Diamond \& Philip H. Dybvig, Banking Theory, Deposit Insurance, and Bank Regulation, 59 J. BUS. 55, 63 (1986). 
Il. Three Traditional Hypotheses That Do Not Fully Explain the Term Structure Mismatch

\section{A. The Checking Account Hypothesis}

One explanation for the fact that banks combine the deposit-taking function and the lending function within a single firm is that these services generate economies of scope: banks gain an economic advantage over other possible lenders through greater access to borrowers' financial information.' This combination may enable banks to obtain reliable information about the investment decisions of the firms to which they have loaned money. Deposittaking provides an important source of information to banks about their lending activities. By observing the checks written against a commercial customer's checking account as well as the flow of deposits into the account, a bank loan officer can determine the size of the borrower's payroll, the salaries of the firm's key personnel, the amount of money paid for supplies, the identity of the firm's key customers, and the seasonal pattern of the firm's receipts. This information may give banks a significant competitive advantage over other intermediaries.

Under the checking account hypothesis, combining financial intermediation with transactional services enables banks to be effective monitors of borrowers because of the banks' privileged access to current information about the financial condition of those borrowers after the loans have been made. ${ }^{10}$ However, the advance of computer technology has dramatically reduced the costs of recording, transmitting, and processing information. Computers have made it possible for non-bank lenders, such as commercial finance companies, to obtain the information they need about borrowers without the necessity of offering checking accounts. For example, computer-based retail information processing services can provide lenders with detailed information about the cash flows and inventories of borrowers that is more current than the information revealed by checking account activity. ${ }^{11}$ In other words, advanced technology has made it possible for firms that compete with banks for commercial loans to obtain virtually the same timely credit and market information that was once available only to banks. ${ }^{12}$ For example, finance companies that are funded with commercial paper have begun to compete with banks. By the end of 1991, finance companies had $\$ 315$ billion in loans

9. Nakamura, supra note 5 , at 133 .

10. Jonathan R. Macey \& Geoffrey P. Miller, The Politicization of a Social Problem, 45 STAN. L. REV. 289, 294-98 (1992).

11. See Jonathan R. Macey, The Inevitability of Universal Banking, 19 BRooK. J. INT'L L. 203, 214-16 (1993).

12. Alan Greenspan, Statement Before the Senate Committee on Banking, Housing, and Urtan Affairs (December 1, 1987), in 74 FED. REs. BULL., February 1988, at 92, 93-94. 
outstanding to U.S. customers. This figure is almost one-half of the $\$ 650$ billion in commercial loans outstanding at the time. ${ }^{13}$

Current evidence indicates that banks generally do not have an informational advantage over other lenders. While weak support for the validity of the checking account hypothesis has come from studies showing that announcements of bank loan agreements are followed by positive abnormal stock returns for borrowers, ${ }^{14}$ these studies are inconclusive. They do not compare the performance of firms borrowing from banks with that of firms borrowing under similar conditions from non-bank firms. Moreover, Dianna Preece and Donald Mullineaux have studied stock price reactions to loan announcements and found that loan agreements with non-bank lenders increased returns to the same extent as loan agreements with bank lenders. ${ }^{15}$ They also found that the number of lenders is an important factor in increasing borrower returns. Both findings are inconsistent with the checking account hypothesis, since it is unlikely that multiple lenders will be able to monitor checking account information as well as a single lender.

Even the strongest proponents of the checking account hypothesis acknowledge that checking accounts are of most value for monitoring small businesses. A small, single-location business will usually have a single checking account whose information is readily accessible and interpretable by the lender. ${ }^{16}$ In the U.S. and Europe, the growth of national and multinational firms with many locations, coupled with unusually restrictive rules on branching in the U.S., has hastened the demise of the checking account hypothesis. Moreover, U.S. firms doing business in multiple states often must have several banks because the regulatory prohibition on branch banking means that firms' primary banks are unable to expand geographically to meet their clients' needs. Even without such a prohibition, banks would be unlikely to find it cost-effective to follow all of their clients' business, since it is unlikely that all of their clients would expand to the same places.

Thus, although the checking account hypothesis may have had some validity in the past, it is no longer valid, at least for large borrowers, because there are other, better ways for lenders to obtain information about large borrowers than by monitoring transaction accounts. The need for information that is only available through maintaining transaction accounts cannot justify funding long-term illiquid loans with demand deposits except in the case of small banks lending to small borrowers. Indeed, for small borrowers there is

13. Id.

14. Christopher James, Some Evidence on the Uniqueness of Bank Loans, 19 J. FIN. ECON. 217, 218-19 (1987).

15. Dianna Preece \& Donald J. Mullineaux, Monitoring, Contractual Flexibility, and the Capital Market Response to Loan Agreement Announcements (1991) (unpublished manuscript, University of Kentucky).

16. Nakamura, supra note 5 , at 133. 
substantial evidence that the checking account hypothesis retains some validity. ${ }^{17}$ These firms tend to use a single, local bank for their credit and checking needs. ${ }^{18}$

\section{B. The Transformation Hypothesis}

An alternative explanation for the term structure mismatch is the transformation hypothesis offered by Douglas Diamond and Philip Dybvig. ${ }^{19}$ The transformation occurs when illiquid investments are transformed into what are, from the depositors' perspective, extremely liquid investments (demand deposits). As Diamond and Dybvig observe, "[b]anks are able to transform illiquid assets (into liquid assets) by offering liabilities with a different, smoother pattern of returns . . . . Illiquidity of assets provides the rationale for the existence of banks [the combination of transactions services with commercial loans]." 20

A liquid investment is one that the investor can convert into cash at a price close to the present value of the future cash flows of the investment whenever the investor so desires. All else equal, of course, investors prefer to hold liquid investments rather than illiquid ones. Consequently, borrowers forced to offer potential investors illiquid assets must offer such investors a greater return to compensate them for the additional inconvenience of illiquidity. Banks, by issuing demand deposits, "can improve on a competitive market by providing better risk sharing among people who need to consume at different random times."21

Thus, banks improve the operation of the economy by investing in portfolios of illiquid assets and by offering depositors liquid claims (deposits) on the banks' own assets. This conversion of illiquid investments into liquid ones provides a significant benefit to investors-and to borrowers as well. Consider a manufacturing firm with an asset that cannot be used to pay current operating expenses because it is not generating any income at present. Suppose further that obtaining the information necessary to value the future income that will be generated by this asset is very costly to obtain and verify. This asset is illiquid. If, however, the firm can obtain a loan from a bank secured by the asset, it can convert a substantial portion of the asset's value into liquid form

17. See id. at 137.

18. Ninety-one percent of small businesses that have bank lines of credit have checking accounts at the same bank. Gregory E. Eliiehausen \& John D. Wolken, Banking Markets and the Use of Financial Services by Small and Medium-Sized Businesses, Board of Governors of the Federal Reserve System Staff Studies 160 (1990).

19. Douglas W. Diamond \& Philip H. Dybvig, Bank Runs, Deposit Insurance, and Liquidity, 91 J. POL. ECON. 401, 403 (1983).

20. Id. at 403.

21. Id. at 402 . 
while continuing to control the plant. Banks' ability to sell their skill at valuing assets, their ability to allow investors and borrowers to realize economies of scale in investing, and their ability to convert illiquid investments into liquid investments all explain why banks have survived and prospered even though financial intermediation is costly to both lenders (depositors) and borrowers.

Thus, under the transformation hypothesis, the role that banks play in the economy arises from imperfect information and from the costliness of arranging direct investor-borrower transactions. According to Diamond and Dybvig, economic models of asset services

focus on the role of banks' information gathering in the lending process. What is particularly important is information that cannot easily be made public. This includes both information gathered while evaluating the loan (to limit adverse selection) and information gathered in monitoring the loan (to limit moral hazard). In these models, getting a loan from a bank dominates a public debt offering when the cost to the public of evaluating and monitoring the borrower is high. Getting a loan from a bank dominates borrowing from an individual because bank lending can keep both risk-sharing (diversification) costs and information (evaluation and monitoring) costs low. 22

As with the checking account hypothesis the validity of the transformation hypothesis has been undermined by technology. Technological advances have reduced demand for the transformation services traditionally supplied by banks. Money market mutual funds permit depositors to transform cash into highly liquid claims, and securitization allows borrowers to convert illiquid assets into cash. Thus, for example, the percentage of U.S. financial sector assets on deposit in banks fell from $57 \%$ in 1978 to $33 \%$ in $1991 . .^{23}$ During this same period, mutual funds and pension funds increased their market share from $11 \%$ to $25 \% .{ }^{24}$ On the liability side, commercial paper issued by investment banks came to be seen as a superior alternative to bank loans by the largest, highest quality borrowers. At the end of 1991 , non-financial corporations were raising $\$ 107$ billion annually from commercial paper in funding operations that a decade ago had been conducted through bank borrowing. ${ }^{25}$

22. Diamond and Dybvig, supra note 8 , at 58 .

23. Robert Glauber, 4 NEWSLETTER LONDON BUS. SCH. INST. FIN. \& ACCT. 4 (1992-93).

24. Id.

25. Id. This figure is approximately twenty percent of the total money raised through banks. Id. 
The transformation described by Diamond and Dybvig simply represents a straightforward account of the securitization phenomenon. ${ }^{26}$ The process they describe is seen in the securitization of home mortgages and credit card receivables, the process of issuing commercial paper, and even the process of investing in the securities of publicly held firms, so long as those securities are highly liquid. Thus, the transformation hypothesis is inaccurate to the extent that it implies that commercial banks represent the only mechanism by which illiquid assets can be transformed into liquid assets.

Under the transformation hypothesis, the demand for banks' services arises from imperfect information and from the costliness of arranging direct investor-borrower transactions. Consequently, it stands to reason that the demand for these services will decline as markets develop, and in particular as the costs of organizing and communicating information and arranging financial transactions fall. As markets develop, other intermediaries besides commercial banks emerge to provide funds to particularly large borrowers, and banks cease to be unique in this respect. Insurance companies, pension funds, and open-end mutual funds also provide transformation services by taking funds from policy-holders and investors and investing that money in productive assets. Thus, investors in developed economies now have many mechanisms for pooling their funds with other investors to overcome the transformation problem described by Diamond and Dybvig.

Moreover, new assets that provide transformation services are continually being designed. For example, in 1990, IBM Credit Corporation registered $\$ 2$ billion in Variable Denomination Floating Rate Demand Notes. ${ }^{27}$ Investments in these notes are in pure book-entry form and not represented by certificates. When investments are made, investors receive a credit in a special account established for each investor by a bank. The principal amount of each note is equivalent to the initial investment, plus all accrued and reinvested interest and principal, less the amount of redemptions and fees. The notes have no stated maturity, and are payable on demand in whole or in part. They earn interest at a floating rate determined by an IBM committee, but the rate always exceeds the seven-day average yield of taxable money market funds in the United States. IBM uses the funds it receives from these securities in its general financing business.

These accounts are functionally identical to demand deposit accounts at commercial banks. IBM and its investors receive the same transformation

26. Securitization (structured finance) is a process by which a company that seeks to raise cash sells certain of its assets, typically payment obligations, to a special-purpose vehicle or trust, which pays for the issue through bond issues secured by the assets. The first structured financing took place in the early 1970's with the securitization of pools of mortgages and has since expanded rapidly. See generally STEVen L. SChWarcz, Structured Finance (2d ed. 1993).

27. IBM Credit Corporation Prospectus 1-14 (Sept. 21, 1990). 
services received by depositors in commercial banks. Initial investments are as low as $\$ 2500$, and additional investments of as little as $\$ 100$ may be made. Drafts (checks) may be written against these accounts in amounts of $\$ 500$ or more. The IBM money market fund differs from money market mutual funds in that it is an equity investment. Rather, like checking depositors, investors are promised the return of the full amount of their initial investment, plus accrued interest at a variable rate determined by an independent, objective measure.

The demand for bankers' skill in evaluating particular investments, which is an important part of the transformation hypothesis, should be expected to decline as secondary and new issues markets for securities develop. As secondary capital markets develop, business firms will find it increasingly easy to raise capital by making public offerings. The sophistication of the trading markets provides a dependable price-setting mechanism that permits investors to rely on anonymous market forces rather than on the judgment of particular bankers to determine the appropriate prices for investments. In addition, trading markets such as the New York Stock Exchange compete directly with banks' ability to transform illiquid investments into liquid investments for the benefit of depositors.

In light of the large and growing number of mechanisms for transforming illiquid investments into liquid form, at least in developed market economies, ${ }^{28}$ the transformation hypothesis loses much of its force as a justification for the argument that banks are special and therefore in need of special regulatory treatment, such as deposit insurance.

\section{The Demandable Debt and Incentive-Compatible Intermediation Hypothesis}

Charles Calomiris and Charles Kahn offer an interesting and important explanation of demandable debt based on the monitoring problem faced by bank depositors seeking to control bank managers who may either abscond with their funds or engage in other activities detrimental to depositors' interests. ${ }^{29}$ According to Calomiris and Kahn, since bank managers have an informational advantage over depositors as to which projects to finance, they can fund

28. Clearly, the arguments presented above about the demise of the checking account hypothesis and the transformation hypothesis do not apply with equal force in both developing countries and developed countries. In countries without developed securities markets, the information provided by checking accounts may well be an excellent source of information about the cash flows to borrowers. In banking markets where this is the case, the economies of scope between checking account services and commercial lending may still exist, though they may have disappeared from more highly developed markets.

29. Charles W. Calomiris \& Charles M. Kahn, The Role of Demandable Debt in Structuring Optimal Banking Arrangements, 81 AM. ECON. REV. 497 (1991). 
projects that transfer wealth from the depositors to themselves. In the Calomiris and Kahn model, demandable debt acts as a monitoring device because depositors can take their money out of the bank if they become suspicious that management is making inappropriate asset decisions. If enough depositors feel that managers are misbehaving, the bank will liquidate and close. Because banks repay depositors on a first-come-first-served basis, those who invest in monitoring will be the first to discover that bank managers are engaging in risky activities and will be the first in line to demand repayment. This in turn provides a pay-off to monitoring:

The monitors pay the costs of vigilance but receive the benefit of knowing that they will be "first in line" (and thereby receive a higher payment than other depositors) should it become necessary to withdraw their funds from the bank. The depositors who do not monitor are willing to pay the price of being last in line in "bad" states, because they receive a benefit in return; the active monitors keep the banker in line and thereby provide a benefit to the passive depositors. Depositors need not reveal whether they are active or passive; the same contract works for both types. ${ }^{30}$

Monitors benefit from monitoring because they can get their money out before the bankers can abscond or otherwise behave inappropriately in bad times. Non-monitors benefit because monitoring by others reduces the probability of absconding, and because it provides non-monitors with the valuable information that monitors have not called for liquidation.

While interesting and provocative, the incentive incompatibility hypothesis is unconvincing for several reasons. First, the benefits for non-monitoring depositors are far from clear. Bankers may still abscond or make inappropriate investments as long as they leave enough funds in the bank to repay all of the monitoring depositors.

A second shortcoming of Calomiris and Kahn's analysis is that, as with the checking account hypothesis and the transformation process, market developments and technological change raise doubts about its continued validity:

[O]ur framework does not consider the possibility of trade in bank shares. Unlike the historical context in which demandable debt arose, in today's more sophisticated financial markets, shares of financial intermediaries are actively traded. In this richer context, equity trading could conceivably provide a superior disciplinary alternative

30. Id. at 500 . 
to demandable debt and contingent liquidation. For example, leveraged buy-outs offer a possible alternative means to prevent managerial misconduct and provide rewards that make monitoring incentive-compatible. ${ }^{31}$

Finally, a more important problem with the incentive compatibility hypothesis, for purposes of this analysis, is that it does not explain the persistence of demand debt and long-term lending within a single firm in today's highly regulated banking environment. As Calomiris and Kahn acknowledge, "[i]n today's more regulated environment, where . . . deposit insurance makes depositor monitoring less important, demandable debt may persist simply as an artifact of regulation. ${ }^{32}$ The Calomiris and Kahn account of the mismatch in the term structure of banks' balance sheets is not consistent with the existence of deposit insurance. Unlike Diamond and Dybvig's transformation hypothesis, which posits that deposit insurance is potentially desirable to facilitate the transformation of illiquid assets into liquid form, Calomiris and Kahn's analysis presumes that deposit insurance does not exist. Once deposit insurance is introduced, the incentives to monitor disappear for all insured depositors.

III. The Regulatory Hypothesis as an Explanation for the Term Structure Mismatch

An alternative explanation for the combination of financial intermediation and transactional services within banking organizations is that the explicit and implicit guarantees for depositors provided by both formal deposit insurance programs and regulatory policy afford a significant degree of credit enhancement for banks. According to the regulatory hypothesis, the credit enhancement provided by the explicit and implicit government guarantees enables banks to fund their lending activities more cheaply through deposits than through other means, such as equity, commercial paper, or other forms of debt. The regulatory hypothesis does not posit any necessary economic role for the mismatch in the term structure of banks' assets and liabilities. Rather, the mismatch is due to banks' efforts to maximize the amount of the subsidy they enjoy over other intermediaries in the form of explicit or implicit deposit insurance.

There are two obvious objections to the regulatory hypothesis. First, deposit insurance protection is not restricted to short-term bank liabilities like checkable transaction accounts, but extends equally to long-term certificates

31. Id. at 510 .

32. Id. 
of deposit (CDs). Thus, the regulatory hypothesis must account for the fact that banks persist in utilizing short-term demand deposit accounts as their primary source of funding. One reason banks prefer demand deposit accounts over other forms of insured liabilities is that the interest rate that banks must pay to attract these sorts of accounts is usually lower than for insured accounts with longer maturities. The fact that banks prefer to offer short-term liabilities rather than longer-term liabilities may be consistent with the regulatory hypothesis because banks can maximize the amount of the regulatory subsidy by offering short-term liability accounts.

Moreover, it is likely that the greater competition among issuers of longerterm, state-backed securities makes it more attractive for banks to offer shortterm deposit accounts. Longer-term securities issued directly by the government, or by government agencies, are a superior substitute for bank CDs because the secondary trading markets for these securities provide owners with liquidity unavailable to $C D$ owners. Finally, by offering checking accounts, banks are able to obtain funding from relatively small savers whose liquidity needs make their demand for checking accounts highly inelastic.

A second objection to the regulatory hypothesis is that it does not account for the fact that the mismatch in the term structure of banks' assets and liabilities existed prior to the introduction of deposit insurance. ${ }^{33}$ Since the pervasive mismatch in the term structure of banks' assets and liabilities predates the introduction of government subsidies in the form of deposit insurance, the mismatch cannot be explained by those subsidies. In fact, the evidence clearly shows that combining transaction accounts with financial intermediation was quite costly prior to the introduction of deposit insurance, because depositors demanded compensation for the risks of placing their funds in potentially unstable firms. In the United States and other countries this problem was dealt with through the introduction of a system of multiple liability for bank shareholders. ${ }^{34}$ Under this system, shareholders obligated themselves to contribute additional capital, calibrated as a multiple of their initial investment (usually either two or three times the amount of the initial investment), in order to provide the credit enhancement necessary to attract depositors' funds to the bank. Although these multiple liability programs

33. Banks have issued some kind of demandable debt since the Roman Empire. Id. at 509. For centuries, the term structure mismatch has been the preferred method for funding the vast majority of externally-financed investments. Id. at 497. Federal deposit insurance, in contrast, is a result of the New Deal. Anna J. Schwarz, Financial Stability and the Federal Safery Net, in Restructuring BANKING AND FINANCIAL SERVICES IN AMERICA 47 (William S. Haraf \& Rose Marie Schneider eds., 1988); see also Jonathan R. Macey \& Geoffrey P. Miller, Double Liability of Bank Shareholders: History and Implications, 27 WAKE FOREST L. REV. 31, 38 (1992).

34. Macey \& Miller, supra note 33, at 31 . 
reduced the amount of capital stated on the banks' books, they considerably increased the banks' effective cost of capital. ${ }^{35}$

Viewed from a historical perspective, the checking account hypothesis and the transformation hypothesis provided the most convincing explanation for the mismatch in the term structure of banks' assets and liabilities. Combining financial intermediation with transactional services may have been the only way for the economy to transform illiquid assets into liquid funds. As technology evolved and markets developed, however, superior mechanisms for monitoring borrowers emerged and the economies of scope in combining checking account services and financial intermediation disappeared. With the emergence of alternative financing vehicles, particularly securitization, the economy can operate without the transformation services provided by banks. Thus, while the regulatory hypothesis cannot explain the peculiar nature of banks' balance sheets prior to the introduction of government-sponsored depositor protection schemes, it is undoubtedly the most convincing explanation today.

The point here is not that the checking account hypothesis and the transformation hypothesis are wholly unpersuasive as theories for explaining why firms choose to combine transaction account services with commercial lending. Rather, it appears that both of these theories continue to have some validity in that they provide at least partial explanations for the term structure of banks' balance sheets. As markets and technology have developed over time, however, the regulatory hypothesis has emerged as the dominant explanation.

IV. The Inadequacy of the Regulatory Hypothesis as an Economic Justification for Federal Deposit Insurance

While a strong argument can be made that the basic justification for the existence of deposit insurance is the mismatch between the term structure of banks' assets and liabilities, the regulatory hypothesis holds that the reason for the continued mismatch is the subsidy that deposit insurance provides. If the regulatory hypothesis is valid, the obvious thing to do would be to abolish government-sponsored deposit insurance. This would eliminate the subsidy given to banks that offer transaction accounts, and cause them voluntarily to correct the term structure mismatch. Ironically, therefore, abolishing deposit insurance removes the need for it, unless some other justification for it independent of the mismatch can be offered.

Moreover, eliminating deposit insurance would eliminate the need for much of the rest of bank regulation as well. Minimum capital requirements,

35. Id. at 60 . 
limits on lending to particular borrowers, limitations on banks' activities, and restrictions on banks' ability to borrow can be justified on the grounds that they are necessary to protect the government against losses to which the system of guarantees exposes it.

In light of the preceding analysis, the question that remains is whether there is a justification for deposit insurance that is independent of the mismatch in the term structure of assets and deposit liabilities. Besides the collective action problem caused by the mismatch in the term structure of banks' assets and liabilities, two other economic justifications for government-sponsored deposit insurance have been offered. The first concerns banks' unique role in the payments system and the second concerns the information problems that plague depositors, making them unable to fend for themselves as consumers of banking services.

\section{A. The Unique Role of Banks in the Payments System}

It is frequently asserted that government guarantees are necessary to provide a transparent payments system-one in which those accepting checks can worry about the credit worthiness of the check writer without concern for the stability of the intermediating financial institutions. Additionally, the special treatment of banks has been justified on the grounds that they clear transactions and hold large inventories of currency. These justifications should be reconsidered. For years, money market funds, brokers' asset management accounts, and credit cards have competed directly with banks both in providing secure and liquid stores of funds and in clearing transactions. ${ }^{36}$ These changes in payments technology have weakened the link between the money supply and bank deposits. The emergence of competition for liquidity services dictates that any regulation designed to protect the payments system or permit regulators to conduct monetary policy should apply to all financial intermediaries performing such services, not just banks. ${ }^{37}$

\section{B. The Informational Problems Among Depositors}

Another argument that is often used to justify special government protection for banks is that many depositors are small savers who have neither the sophistication to evaluate the riskiness of the intermediaries they entrust

36. Diamond \& Dybvig, supra note 8, at 61-62.

37. The argument that banks no longer play a unique role in the payments system is particularly strong in Europe. There, non-bank firms such as OM Gruppen $A B$ in London and Stockholm routinely clear money market instruments and derivative products, such as options and futures on stocks and stock indices. Jonathan R. Macey, The Future Regulation and Development of the Swedish Banking Industry (Occasional Paper No. 56, Center for Business and Policy Studies, May 1994), at 23-24; see also Glauber, supra note 23 , at 500 . 
with their savings nor the expertise to develop contractual solutions to deal with this risk. This argument also merits skepticism. In an environment without government guarantees, small depositors needing extra protection would be able to purchase it from private insurers. Moreover, if permitted by law, banks could guarantee depositors' funds on the basis of the personal liability of the banks' shareholders or by investing these deposits in government-backed securities.

There is a strong economic argument against government protection of depositors (or their private sector co-insurers) in the event of bank failure. This argument is based on the notion that private sector actors have an incentive to monitor their banks only if they (or their guarantors) face some risk of loss. ${ }^{38}$ Depositor monitoring, in turn, plays an important role in strengthening the banking system by imposing a kind of market discipline upon banks. Such discipline reduces banks' proclivities for excessive risk-taking.

Depositor monitoring can best be understood through simple marginal cost analysis. In the absence of implicit or explicit government guarantees, depositors can be expected to monitor and constrain banks' risk-taking until the cost of an additional unit of monitoring exceeds its benefit. Monitoring costs come from researching the solvency and future prospects of banks, drafting restrictions on banks' investment policies, and developing reporting systems to monitor adherence to restrictive agreements; monitoring benefits come in the form of a higher probability of repayment by the bank. Moreover, as the Calomiris and Kahn analysis described above indicates, effective depositor monitoring does not require that all depositors serve as effective monitors. ${ }^{39}$ A bank can be effectively monitored by a relatively small number of depositors, because even a few monitors can start a crippling run by withdrawing their funds if they think bank management is taking excessive risks. ${ }^{40}$

It has been argued that market discipline by depositors will manifest itself in the precipitous withdrawals of uninsured funds on the basis of unfounded rumors. This argument is based on the incorrect assumption that the low cost of withdrawal from checking accounts implies that depositors will not impose constraints on bank risk-taking, but instead will simply withdraw their funds in anticipation of an impending bank failure. ${ }^{41}$ The precipitous withdrawal argument suffers from three principal weaknesses. First, while it is true that it is not costly for uninsured depositors to withdraw their funds, they must

38. Jonathan R. Macey \& Geoffrey P. Miller, Bank Failures, Risk Monitoring, and the Market for Bank Control, 88 CoLUM. L. REv. 1153 (1988).

39. See supra Part I.C.

40. Calomiris \& Kahn, supra note 29 , at 500 .

41. Helen Garten, Banking on the Market: Relying on Depositors to Control Bank Risk, 4 YALE J. ON REG. 129, 153-57 (1986). 
incur search costs in finding an alternative repository for these funds. Second, the argument presupposes a race among uninsured depositors to withdraw their money from a troubled bank, but since each depositor faces a risk of losing this race he has an incentive to engage in monitoring. Similarly, the threat of precipitous withdrawals provides bankers with an incentive to furnish uninsured depositors with current information about the state of the bank-or to change the terms of their contractual agreements with borrowers. Consequently, the threat of depositor withdrawal is likely to have a beneficial rather than a harmful effect on depositors, particularly when large, sophisticated depositors perform the monitoring.

Finally, the argument that monitoring by uninsured depositors will lead to bank runs misses the point that, contrary to popular myth, bank runs are not spontaneous events that strike randomly at strong banks and weak banks alike. Bank runs occur because banks have badly-managed loan portfolios or other excessive exposure to risk. ${ }^{42}$ In other words, the available empirical evidence indicates that bank runs occur on banks that require market discipline. ${ }^{43}$ Thus, the withdrawal of depositor funds from isolated banks should be viewed as an indication that depositors are monitoring their banks, not as a sign of market failure.

\section{A Public Choice Explanation for Deposit Insurance}

The public choice (or interest group) theory of regulation "asserts that legislation is a good demanded and supplied much as other goods, so that legislative protection flows to those groups that derive the greatest value from it, regardless of overall social welfare." 44 In other words, the public choice theory of regulation applies generally accepted principles of rational economic behavior to decisions made by politicians, bureaucrats, and interest groups. This theory leads to predictions that are quite different than those of the traditional public interest theory of regulation, which holds that regulation is

42. Cates, Management Discipline: The True Bulwark Against Banking Crisis, IssuEs IN BANK REG., Winter 1985, at 4, 4-5.

43. T. Hannan \& G. Hanweck, Fin. Structure Section, Div. of Research and Statistics, Bd. of Governors of the Fed. Reserve SYs., WorkIng Paper in Banking, Finance, AND MICROECONOMICS, No. 86-1, BANK INSOLVENCY RISK AND THE MARKET FOR LARGE CertifiCates of Deposit (Apr. 1986) (observing interest rate data for certificates of deposit of five different maturities at 300 different banks and concluding that market exacts a price for risk taking); Eugenie D. Short, Bank Problems and Financial Safety Nets, ECON. REV. Fed. RES. BANK DALLAS, Mar. 1987, at 17, 25-26 (describing evidence suggesting depositors in medium and small sized banks demand higher risk premiums from problem banks), Herbert Baer \& Elijah Brewer, Uninsured Deposits as a Source of Market Discipline: Some New Evidence, ECON. PERSP. OF THE FED. RESERVE BANK CHICAGO, Sept./Oct. 1986, at 23 (examining ratio of equity market value to total assets and variance of returns on bank equity and concluding that uninsured depositors exert market discipline on banks).

44. Richard A. Posner, Economics, Politics, and the Reading of Statutes, 49 U. CHI. L. REv. 263,265 (1982). 
designed to benefit the public by solving collective action problems and other sorts of market failures. ${ }^{45}$ Public choice theory holds that political decisionmakers behave much like private sector consumers and businesses-they attempt to maximize their own utility, often at the expense of overall societal welfare. ${ }^{46}$

\section{A. Self-Interested Behavior of Affected Groups}

Under the public choice theory of regulation, interested parties form distributional coalitions in order to trade resources, in the form of influence, money, and power, in exchange for regulations that provide private benefits to the coalitions' members. The public choice theory of regulation focuses on the differing organizational costs that face rival political coalitions. The theory assumes that a political coalition will form when the benefits from achieving wealth transfers from the legislature outweigh the costs of organizing. For a number of reasons, some groups will be able to organize into distributional coalitions more cheaply than others. ${ }^{47}$ In particular, groups that have already formed into coalitions for other reasons, such as mutual professional interests (lawyers, doctors, bankers), will find that the marginal costs of diverting their activities to the political arena are far outweighed by the benefits from the favorable legislation such activities can procure..$^{48}$

The public choice theory of regulation recognizes that well-organized special interest groups are better able to provide the political support that politicians need for survival than are highly diffuse, disorganized citizens. Consequently, politicians who are unable or unwilling to satisfy interest group constituents will be driven from office by rival politicians more capable of supplying the laws that interest groups demand. To take a simple example, suppose a proposed piece of legislation would cost the U.S. public $\$ 250$ million and would transfer $\$ 100$ million to a particular interest group. The 250 million individual members of the public who would pay for this legislation through additional taxes of $\$ 1.00$ (or, more likely, a share of the interest on additional governmental borrowing of $\$ 250$ million) would not find it in their interest to organize into an effective political coalition to oppose this wealth transfer. The costs of organizing and obtaining information about the merits of the proposed legislation would be many times greater than the $\$ 1.00$ per person cost of the legislation. Consequently, it would be rational for most

45. See Robert E. MCCormick \& Robert D. TOllison, Polticlans, Legislation, aNd the ECONOMY: AN INQUIRY INTO THE INTEREST-GROUP THEORY OF GOVERNMENT 3 (1981).

46. See id. at 5 .

47. Id. at 16-18; see also MANCUR OLSON, THE Rise AND DECLINE OF NATIONS: ECONOMIC Growth, Stagflation and Social Rigidities 18 (1982); Geoffrey P. Miller, Public Choice at the Dawn of the Special Interest State: The Story of Butter and Margarine, 77 CAL. L. REV. 83 (1989).

48. See Miller, supra note 47. 
individuals to remain ignorant about the effects of the proposed wealth transfer rather than to incur the information and organizational costs necessary to become informed and oppose it effectively. By contrast, the well-organized interest group beneficiary of the regulation would pay up to the full amount of the proposed wealth transfer in order to achieve passage of the legislation that effects the transfer.

Thus, although qualifications are sometimes in order, a useful generalization is that the public choice theory of regulation posits that legislation will be characterized by concentrated benefits for discrete groups and widely dispersed costs. This is because legislatures pass laws to benefit those groups that are able to pay for or trade political support in exchange for obtaining passage of such laws. The costs of legislation are borne by those who are in the worst position to object to them-the amorphous and disaggregated public. Moreover, the realities of the political marketplace provide strong incentives for politicians themselves to search actively for issues in which the winners are easily identified and the losers are poorly identified. ${ }^{49}$ Legislation that benefits special interest groups is paid for by the losers through higher taxes, increased regulatory burdens at all levels, and higher prices for goods and services. ${ }^{50}$

\section{B. Banks as Economic Beneficiaries of Deposit Insurance}

Applying the public choice theory of regulation to the issue of deposit insurance, the logic of protecting depositors is clear. The primary beneficiaries of this sort of protection are the banks themselves: government guarantees of their liabilities enhance their credit and therefore lower their costs of doing business. $^{51}$ Government guarantees of bank liabilities are less helpful to depositors than they appear, since some, if not all, of the benefits of credit enhancement are eroded by the lower interest rates banks must pay for deposits. The distinct political advantage of government guarantees of bank liabilities is that such guarantees rarely, if ever, meet with concerted political opposition. This is because the diffuse citizens who must bear the costs of these programs generally view themselves as beneficiaries of the schemes, which are marketed by bureaucrats, politicians and interest groups as consumer protection devices. Similarly, once a bank has collapsed, the political pressure

49. Jonathan R. Macey, Promoting Public-Regarding Legislation Through Statutory Interpretation: An Interest Group Model, 86 COLUM. L. REV. 223, 229 (1986) ("Market forces provide strong incentives for politicians to enact laws that serve private rather than public interests and hence statutes are supplied by lawmakers to the political groups or coalitions that outbid competing groups.").

50. Jonathan R. Macey, Transaction Costs and the Normative Elements of the Public Choice Model: An Application to Constitutional Theory, 74 VA. L. REV. 471, 478-80 (1988). 1975-76

51. In particular, smaller banks benefit from this credit enhancement. See Roe, supra note 2, at 
for a government bailout can become very great, since the creditors have incentives to form an effective political coalition demanding repayment on the grounds that government supervision created a reasonable expectation of government protection from risk of loss.

The existence of sweeping government guarantees for banks helps the banking industry in other, more subtle ways. First, because the protection is contingent, it does not appear in the government's budget as an expenditure and so does not increase the size of the government's budget deficit-at least until the guarantee is called upon in the event of bank failure. This makes it a relatively cheap form of political benefit for politicians to supply. Moreover, creditor protection is attractive to bankers and politicians because, by making creditors indifferent to bank failure, such protection removes bank safety as a salient political issue, an important benefit for politicians since bank failure has in the past toppled governments. ${ }^{52}$ Government protection for bank creditors renders depositors less sensitive to the rate of bank failures in the economy. Thus, despite the strong economic arguments in favor of forcing depositors to face risk of loss, most advanced economies nevertheless provide either explicit or implicit guarantees to bank depositors (although few, if any, provide guarantees as extensive and costly as those available under U.S. law).

\section{The Continuing Existence of Deposit Insurance}

In our view, the social costs of deposit insurance are so high-as illustrated by the catastrophic losses taxpayers incurred in the savings and loan debacle of the $1980 s^{53}$-as to suggest the desirability of repealing all forms of government-sponsored insurance. Repeal of deposit insurance, if it were politically feasible, would not only protect the government against such catastrophic losses in the future but would also eliminate the need for many costly regulations now imposed on the banking industry in order to protect the government against its contingent liability.

It appears unlikely, however, that Congress will scale back or repeal government-sponsored deposit insurance, at least in the short run. As we have

52. The paradigmatic example of a government's collapse due to bank failure is the resignation of the Austrian government on June 18,1931 following the May 11, 1931 collapse of Austria's largest bank, the Kreditanstalt. The closure of over one-third of American banks between 1931 and 1933 had a significant effect upon President Hoover's political fortunes. JONATHAN DAVID ARONSON, MONEY AND POWER 27-37 (1977). A bank failure today is unlikely to topple a government; however, such a failure might well be sufficient to result in changing particular elected representatives. In this sense, while the systematic threat to government of a bank failure is not large, the political costs of bank failure to particular representatives may continue to be quite high. See, e.g., KATHLEEN DAY, S \& L HELL 307-27 (1993).

53. The total estimated cost of these failures is $\$ 150$ billion and rising. James $\mathbf{R}$. Barth \& $\mathbf{R}$. Dan Brumbaugh, Jr., Depository Institution Failures and Future Costs: The Role of the Moral Hazard and Agency Problems, in Rebuilding Public Confidence Through Financial Reform, 1992 Oho St. C. OF BUS. CONF. PROC. 
noted, deposit insurance tends to be a popular program. In spite of the disaster of the 1980s, Congress has not reduced the insurance ceiling-clearly excessive for the protection of small depositors-of $\$ 100,000$ per depositor per institution. ${ }^{54}$

Notwithstanding these difficulties, devices for facilitating the phase-out of deposit insurance are worth exploring. Other countries have attempted to repeal their systems of deposit insurance. Argentina, for example, reacted against large losses in its deposit insurance system by enacting legislation that prohibits the central bank from making good on depositor losses and severely restricts the availability of lesser measures such as temporary liquidity assistance..$^{55}$ This promise not to bail out bank depositors is backed not only by legislation, but also by express commitments from principal governmental officials. ${ }^{56}$ Beyond this, any attempt by the Argentine government to pay off depositors would probably undo the program of monetary reform that has been the centerpiece of Argentina's recent economic recovery. ${ }^{57}$

Although the Argentinian experience is obviously distinct from that of the United States, the fact that a major economy has succeeded in taking effective measures to repeal its program of deposit insurance suggests that similar reforms should not be ruled out altogether, at least in the long run. For effective reform to take place, it will be necessary for the economy to offer small savers an investment vehicle that emulates the desirable features of insured deposits: a highly secure account that consumers can use to conduct economic transactions while earning a modicum of interest on savings. It is not commonly realized that such a vehicle already exists in the United States, without the backing of deposit insurance: money market mutual funds backed by short-term government securities. These funds are extraordinarily secure and offer transaction services which increasingly emulate the services offered by insured deposit accounts. If consumers come to recognize the functional interchangeability between these uninsured accounts and traditional insured deposit accounts, it may be possible to reduce deposit insurance gradually, eventually converting it into an optional and strictly limited program for banks and thrift institutions.

In the short run, however, it is clear that deposit insurance is a feature of the American political landscape. Given that the government does not have the willpower, under current conditions, to allow a major bank to fail without

54. Phillip F. Bartholomew, Cong. Budget OfF, Reforming Federal Deposit Insurance 34-37 (Sheila Harty ed., 1990).

55. See Geoffrey Miller, Politics of Deposit Insurance Reform: The Case of Argentina, 1 U. CHI. L. SCH. ROUNDTABLE 129 (1994).

56. Id. at 148 .

57. See id. at 137-41. 
protecting its depositors, the question becomes what, as a practical matter, can be done to minimize the costs and perverse effects of the program.

\section{Alternative Justifications for Deposit Insurance}

The best argument for deposit insurance protection in an imperfect world is that, in the absence of explicit guarantees, there will be considerable confusion about the actual extent of the government's commitment to depositors. This confusion will create pressure on the government to bail out all depositors in case of loss. In part this is because of the political costs to politicians of allowing large losses to fall on a potentially powerful political coalition-frustrated depositors-and in part it is because the existence of pervasive systems of bank regulation and supervision by central bankers and other regulators gives rise to the expectation that bank depositors are protected by the government. ${ }^{58}$

Thus, deposit insurance might be justified, not because it places a cap on the amount of money that can be lost by depositors, but because it enables a democratic government to make a credible commitment to bank depositors ex ante that limits the amount of the government's exposure to the amount of the deposit guarantee. Without such an explicit limit, fixed claimants in banks can argue that they relied on the pervasive system of government oversight and regulation and that therefore the government should indemnify them for their losses. Of course, it must be remembered that the justification for governmentsponsored deposit insurance programs is that such programs deter even more sweeping intervention later on, as has happened in Sweden and Israel and, for a time, the United States, when the government sent signals that all creditors would be protected in case of bank failure.

An alternative regulatory strategy is called "constructive ambiguity." Under this approach, the government offers a set of vague guarantees as a substitute for explicit depositor protection. The argument for constructive ambiguity is that some of the perverse effects of regulation on market actors' incentives can be reduced if there is ambiguity about how regulators will respond to particular events. Thus, for example, if bankers do not know that the deposits in their banks will be protected in the case of bank failure because the government's plans for dealing with crisis are ambiguous, they might refrain from excessive risk-taking. And if customers do not know that the government will protect them from loss, they will monitor the activities of their banks. Unfortunately, constructive ambiguity has had a mixed record, at best, with respect to deposit insurance guarantees. Constructive ambiguity can

58. Thus it is not surprising that, in both Israel and Sweden, the two industrialized countries without explicit protection for depositors, the government responded to domestic banking crises by issuing blanket government guarantees to all fixed claimants. Macey, supra note 37, at 78-79. 
produce the worst of all worlds, because creditors, particularly foreign creditors, may demand a risk premium for investing in banks without explicit government guarantees, while bankers and depositors can play a game of chicken with regulators, in the belief that it will be political suicide for the government to decline to protect uninsured depositors. Ambiguity of this sort is an implicit part of any bank regulatory system in which people are led to believe that the government may-or may not-intervene to protect some or all of the creditors of an insolvent bank above the amounts specified in the insurance limits set by law.

The European Union (EU) directives remove constructive ambiguity by requiring that banks in the EU protect consumers on at least the first $\$ 19,200$ of deposits. ${ }^{59}$ Also, in the wake of the collapse of the Bank of Commerce and Credit International, the EU has decided that the responsibility for providing deposit insurance protection should belong to the country that supervises the consolidated bank, not the host country. ${ }^{60}$ The regulatory hypothesis developed here raises the question whether the relatively low levels of protection offered by the EU are high enough to represent a credible commitment on the part of regulators not to bail out depositors whose investments exceed the minimums. If depositors can claim credibly that they could not fend for themselves, and that they reasonably expected that their deposits would be protected in higher amounts than the EU minimums, then the pressure on political actors to provide significantly higher levels of protection may be irresistible.

\section{Conclusion}

In this Article we have examined the checking account hypothesis and the transformation hypothesis, efficiency-based explanations offered by economists to account for the remarkable combination of financial intermediation and transactional services offered by banks. We have argued that these traditional economic justifications, however valid they may have been in the past, have been weakened considerably by changing market conditions and new technologies that have given rise to superior, low-cost substitutes for the services traditionally offered by banks. An alternative economic explanation for the mismatch between the term structure of banks' assets and liabilities is Calomiris and Kahn's monitoring hypothesis. This hypothesis cannot justify the existence of deposit insurance because deposit insurance deprives investors of the incentives to monitor that underlie the monitoring hypothesis itself.

59. Richard J. Herring, Divergent Regulatory Reform in the Major Banking Markets, in Rebuilding Public Confidence THRough FinANCIAL ReForm, supra note 53, at 61.

60. Id. 
We have also argued that a better explanation for the persistence of the mismatch in the term structure of banks' assets and liabilities is a regulatory hypothesis. Under this hypothesis, the mismatch is explained as the means by which banks maximize the amount of the subsidy they obtain from the credit enhancement that government sponsored deposit insurance programs represent.

Our analysis of the decline of the economic justifications for the mismatch in the term structure of banks' assets and liabilities has important implications for the policy debate concerning the need for federally sponsored deposit insurance programs. We argued that the desirable public policy would be to phase out and eventually eliminate this costly and poorly-designed program. Political reality, however, dictates that deposit insurance remain in place, at least in the short term. This reality is a result of the pervasive systems of government regulation and monitoring for banks that exist in every developed country, which cause depositors to expect to be bailed out in case of bank failure. In most developed countries, governments and citizens have an implicit agreement that depositors will be protected against loss in case of bank failure. If the government does not limit its exposure through deposit insurance, it may end up bailing out all depositors. Attempts to limit deposit insurance must be explicit and transparent, and must reliably precommit the government not to bail out depositors in toto. Ideally, this would involve a promise not to insure deposits at all. In light of contemporary realities, however, deposit insurance enables the government as insurer to make a credible commitment to cap its losses in cases of bank failure to the amounts specified in the regulations. 